\title{
Chapter 8 \\ The 2020 Violent Change in Government in Kyrgyzstan Amid the Covid-19 \\ Pandemic: Three Distinct Stories in One
}

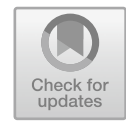

\author{
Asel Doolotkeldieva
}

\begin{abstract}
The day after the election night, on October 5th of 2020, several thousand Kyrgyz citizens poured in the direction of the main square of the capital Bishkek to denounce fraudulent elections. An estimated 1,250 people were injured, and one young person died. This third violent change of government in Kyrgyzstan's short history of independence can be best understood as a combination of three distinct stories coming together under an unprecedented external shock produced by the coronavirus. First, a genuine citizen mobilization was triggered by the pandemicrelated economic decline and rigged elections. Second, the initial peaceful protest was hijacked, to the surprise of the many, by a populist leader capitalizing on longexisting societal polarization. Third, the spectacular unfolding of the intra-opposition struggle downplays an important process of oligarchization, underlying the shaky grounds of patronal presidentialism in pluralist systems.
\end{abstract}

Keywords Revolution $2020 \cdot$ Regime change $\cdot$ Populism $\cdot$ Kyrgyzstan

\subsection{Introduction}

The day after the parliamentarian election night, on October 5, 2020, several thousand Kyrgyz citizens poured in the direction of the main square of the capital Bishkek to denounce fraudulent elections. After nightfall, this large peaceful protest grew into an unexpected dramatic storming of the White House ${ }^{1}$ as police used rubber bullets and tear gas to attempt to disperse the crowds. An estimated 1,250 people were injured, and one young person died. In the night between the October 5 and 6 , several politicians who were illegally freed from prison joined the protesters to take advantage of the public discontent. During the week after the storming of the White House, these forces competed among each other while President Sooronbay Jeenbekov went missing for a few days, leaving the ruling elite in complete disarray.

\footnotetext{
${ }^{1}$ The White House is a seat of the president and parliament of Kyrgyzstan.
}

A. Doolotkeldieva ( $($ )

OSCE Academy in Bishkek, Bishkek, Kyrgyzstan 
It is in these days that the former politician, Sadyr Japarov, released from prison where he was serving a sentence since 2017 for "forcible seizure of power and alleged kidnapping," made forceful attempts to get the outgoing parliament to vote for him as Prime Minister. Fearing further clashes between Japarov's supporters and those of the competing camp, the resuscitated President Jeenbekov decided to back Japarov's candidacy for Prime Minister while hoping to continue through with his own mandate. However, on October 13th, in another unexpected turn, Jeenbekov resigned, leaving power entirely in Japarov's hands. This third violent change of government in Kyrgyzstan's short history of independence conceals more stories than the surface suggests.

In this chapter, I will provide three distinct accounts that can best explain both the unexpected eruption and the outcomes of the mass uprising in the fall of 2020. First, the economic crisis provoked by the Covid-19 pandemic on the one hand, and the dynamics of patronal politics in the dominant political machine on the other, have generated a negative public opinion towards the ruling elite, which was palpable prior to the parliamentary elections in October of that year. These two crucial factors formed a combustible background against which the perceived rigged elections served as a trigger to spark an initially peaceful mobilization. Yet, the subsequent rise of the mid-ranked populist leader Japarov amidst other wealthier and more established competing politicians cannot be explained fully by the immediate context leading to the uprising. As the second account unfolds, the rise of Japarov as an unexpected outcome of the intra-opposition struggle for power is a result of long-fostered popular anti-establishment sentiments that have played against not only the regime but also the established opposition. Lastly, the mass uprising and a spectacular rise of a populist leader conceals a salient regime-oligarchy dynamic that would destabilize Jeenbekov's political machine in the future, independent from the above societal and opposition developments. As this final story suggests, patronal presidentialism was facing major challenges from within as a powerful oligarchic group rose to contest the established sources of power thanks to money. These three separate stories, combined in a historical conjuncture of long-rising anti-elite sentiments, boosted by an unprecedented external shock produced by the coronavirus, and the rise of the power of money as an alternative to the traditional power of the "administrative machine," can best explain this unexpected violent change of government.

The following analysis rests on privileged access to political actors and elites prior, during, and after the October events. Based on the ethnographic methodology, I collected 30 in-depth semi-structured interviews with ordinary participants of peaceful demonstrations and 5 members of the People's Defence Groups; 14 elite interviews including 4 MPs, 4 members of political parties, 2 officers of the Special Security and National Guard, 2 government officials, 2 members of the business elite; and 3 interviews with independent journalists. Second, I have conducted non-participant and participant observation of various protests and civil society meetings during the October events. Third, I have also conducted mass media and social media analysis of electoral campaigns and online groups supporting various political 
forces. ${ }^{2}$ The present chapter follows the method of process-tracing that is helpful to construct a chain of events and processes that led to and formed the October uprising (Alexander and Bennett 2005).

\subsection{Kyrgyzstan's Mass Mobilizations and the Limits of Patronal Presidentialism}

The "October" or "Youth" Revolution ${ }^{3}$ is the third mass mobilization that resulted in a regime's ouster. In all of Kyrgyzstan's uprisings, the system of “patronal presidentialism" has been at the center of societal critique and opposition contestations. Hale (2005, 2013) interpreted Kyrgyzstan's first “Tulip Revolution” of 2005, as other preceding "color revolutions" such as in Ukraine and Georgia, and subsequent revolutions in post-Soviet countries as results of the dynamics within patronal presidentialism. In his reading, revolutions are swings within the regime-elite relationships, in which elites tend to challenge the patron if the latter is perceived as a lame duck. Usually, patronal presidents face an intra-elite challenge in times of succession or a significant drop in popularity.

I draw on the concept of patronal presidentialism as it offers a valid description of political machines and one of the important sources of change located within elite contestations in Eurasia. Indeed, despite regular changes in formal rules of the game, patronal presidentialism remains the main logic ordering power and decisionmaking. In Kyrgyzstan, despite the formally enlarged powers of political parties and the parliament since $2010,{ }^{4}$ political actors, inside and outside the political machine, orient their strategies and tactics around the signals emanating from presidency.

However, if we follow Hale's explanation of the political change, we need to concentrate on the dynamics of elite contestations only. The model ends up overlooking factors lying outside of the political machine, thus reducing contingency and uncertainty inherent to any polity. Dynamics within the patronal presidentialism prior to the October uprising do not fully fit the mechanisms of change, described in Hale's model. In fact, the dynamics of patronal politics were not connected to a president's succession phase since President Jeenbekov was only halfway through his term and most elites had vested interests in his continuation in connection to their own re-election into the new parliament. His removal would jeopardize significant financial investments they made in the parliamentary election. That is why the

\footnotetext{
${ }^{2}$ I am thankful to my colleagues-Nargiza Muratalieva, Elmira Nogoibaeva, Nurgul Esenamanova, Amanda Wooden, Erica Marat, and Eugene Huskey—for thought provoking discussions and correspondence.

${ }^{3}$ In this chapter, I refer to revolution as a category of practice, not a category of analysis, in order to put forward local understandings of events and usages of the term.

${ }^{4}$ For the analysis of constitutional changes, see Fumagalli, M. (2016). Semi-presidentialism in Kyrgyzstan. In Semi-presidentialism in the Caucasus and Central Asia. Palgrave Macmillan: London; Huskey, E. (2007). Eurasian semi-presidentialism: The development of Kyrgyzstan's model of government. In Semi-presidentialism outside Europe: a comparative study. Routledge: London.
} 
uprising against patronal presidentialism was unexpected to political actors, both inside and outside the political machine. ${ }^{5}$

Also, Hale's model is not operational as it does not allow to know when exactly the public perception of president's unpopularity will tip towards the negative end. In such highly informal systems, the presidency constantly engages in all sorts of manipulations to retain its power. To the public and opposition, these developments do not automatically send clear-cut messages leading to the formulation of a unanimous public opinion. For example, the situation in which in 2017 the former president Almazbek Atambaev sought to appoint his political heir Sooronbai Jeenbekov was presenting an opportunity for elite contestations. The successor enjoyed only $3 \%$ of popularity against his main contender Omurbek Babanov with $35 \%$ of popularity prior to elections, while Atambaev himself earned quite a controversial reputation by the end of his term with $31 \%$ only (IRI 2017). Yet, this perfect constellation did not produce a strong public opinion that would serve the interests of the opposition although Atambaev was later sacked by his heir. In other words, perceptions of lameduck syndrome can be articulated outside of the dynamics of patronal presidentialism, in connection to a wider context, unexpected events, latent societal processes, and elite strategies whose outcomes might be far from intended.

In my preliminary analysis of the recent regime ouster, I seek to highlight contingency and uncertainty of events as the key element of mass mobilizations in the absence of regime repression. This approach emanates directly from the empirical phenomenon that informs the necessity to conceptualize the elite strategies and public opinion nexus more accurately. Such dramatic events open the door to a multitude of public perceptions, fears, concerns, hopes and opinions, whose magnitude and diversity are beyond the reach of elite strategies. For instance, one could hardly anticipate that a widely popular rich businessman Omurbek Babanov would lose his popularity under the street pressure within days. The rise of a mid-ranked former MP, Sadyr Japarov, as a winner of the struggle, was also a complete surprise to the many. Finally, no one expected that the regime of President Jeenbekov would fail so quickly, just a weak after the unrest. Neither the elites nor the public could keep up with the rapidly developing political arena of those days and weeks. Elites could only partially adjust their strategies to a multitude of public opinions forming at different levels of society and producing outcomes that no one had a full control of. Thus, my account is purposefully empirical; new data keeps emerging, and the application of standard models of explanation tends to risk closing the discussion of unfolding dynamics at a premature stage. ${ }^{6}$ I will now turn to the discussion of these dynamics in the following sections.

\footnotetext{
${ }^{5}$ Interviews with members of elites, Bishkek, 2020-2021.

${ }^{6}$ I did not, for example, include the possibility of foreign influences as they manifested themselves in various forms and degrees in the previous revolutions. On the foreign influences in previous revolutions, see Ó Beacháin, D., \& Polese, A. (2008). American boots and Russian vodka: external factors in the colour revolutions of Georgia, Ukraine and Kyrgyzstan. Totalitarismus und Demokratie, 5(1), 87-113.
} 


\subsection{Citizen Mobilization Against Rigged Elections Amid the Covid-19 Pandemic and Patronal Presidentialism}

Two significant factors can best explain popular indignation with Jeenbekov's rule which was ultimately expressed in the uprising on October 5, 2020. These include a sharp economic decline and a negative perception of governmental management of the Covid-19 pandemic on the one hand, and the perceived usurpation of power by the presidential political machine in relation to the parliamentary election on the other hand. Citizen mobilization was triggered by the incoming election results according to which only 'parties of power' were accessing the parliament. In Kyrgyzstan's recent history, such socio-economic situations have already generated mass uprisings in the past. The "Tulip Revolution" of 2005 was partly due to neoliberal reforms which created economic inequalities for the rural poor (Pelkmans 2005) and were triggered by electoral fraud (Tucker 2007). The "April Revolution" was triggered by the energy crisis and increased electricity tariffs, a situation that was used by ordinary people to overthrow Bakiev's dictatorship in April 2010 (Wooden 2014; Reeves 2010).

Although more research is needed into understanding the short and long-term effects of the Covid-19 pandemic on Kyrgyzstan's economy and the well-being of ordinary families, the existing data and my fieldwork suggest that the governmental management of the pandemic led to a negative public opinion of the authorities. The existing data shows that the pandemic had a significant effect on people's socioeconomic situations and consequently in the drop in confidence in the authorities and the president. According to a recent national survey, $22 \%$ of households had at least one member losing her job in the country or being forced to come back from abroad due to the loss of a job there. Labor income was reduced by $37 \%$, income from sales of products from private plots by $16 \%$, and remittances-by $16 \% .^{7}$ Another study reveals that the levels of unemployment and labor uncertainty among labor migrants were as high as $49 \%$ and $11 \%$, respectively (Vesterbye et al. 2020). Every third citizen is at the brink of poverty by the end of the first year of the pandemic (World Bank 2021). Prior to the lockdown, the economic situation was already listed high in people's preoccupations. In 2019, unemployment (67\%) and corruption (54\%) were highlighted by respondents as top challenges that the country faced (IRI 2019). The economic decline has produced a significant drop of confidence in authorities. As a social survey conducted in June 2020 (at the beginning of the Covid-19 summer peak) demonstrates, only $40 \%$ of respondents cumulatively had "a lot of confidence" or

\footnotetext{
${ }^{7}$ See results of the national survey "Ob itogah vyborochnogo obsledovania "Vlianie pandemii Covid-19 na domashnie hozyastva" [Results of sample survey "The effects of Covid-19 pandemic on households"], conducted by the National Statistics Committee in cooperation with UNICEF during the period between 15 October and 15 November 2020. 4954 households participated in the survey.
} 
"some confidence" in President Jeenbekov. Whereas in 2019, the same survey found that $87.5 \%$ of respondents had "moderate" and "high confidence" in him. ${ }^{8}$

Grievances related to human losses and economic insecurities featured prominently in my interviews with ordinary citizens who took part in the October 2020 uprising. In the interviews with the author, they reported that the pandemic has exposed the "real nature of politicians, their corruption, irresponsibility and incompetence." The pandemic mismanagement was especially highlighted by rural residents, whose economic activities depend on the openness of borders, as one source of their indignation in the run-up to the election day: "Since March there is no work in the village; people cannot go to Russia for work. People have nothing to occupy themselves. Politicians left people to die but got active again before the elections. But we saw how dirty the electoral campaign was. Since my propiska [voter registration] is in the village, I was there during the vote. But after voting, I took a trip to Bishkek on the same evening and was following news from here. The next day I went to the main plaza, I knew that there would be a revolution."9

While the Covid-19 pandemic has worsened individuals' economic situations, abuse of power by the ruling elite in connection to the elections and corruption was another source of people's anger and motivation to protest. In a 2019 survey, 92\% of respondents believed that corruption was either a "big" or "very big" problem in the country. $72 \%$ assessed the government's performance regarding this issue as insufficient. Corruption perceptions have been on the rise showing $93 \%$ and $73 \%$ respectively for the same questions in 2015; 68\% thought the levels of corruption were "high" in 2009, and 61\%-in 2006 (IRI 2019). These growing perceptions are partly linked to the increased exposure of corruption cases thanks to journalistic investigations which focused in recent years on the highest echelons of power, including President Jeenbekov himself. The case of massive corruption inside the State Customs became the most scandalous example of these public scandals and a ticking bomb for the past and present presidents. This case and the lack of response from the authorities were mentioned repeatedly by participants of the October uprising.

In 2019, a consortium of independent mass media published a series of investigations unraveling massive corruption schemes that involved the then head of the State Customs Service, Raimbek Matraimov, whose illegal business helped him to allegedly move $\$ 700$ million out of the country (OCCRP 2019, Radio Azattyk

\footnotetext{
${ }^{8}$ See the results of the social survey "Social and Political Impact of COVID-19 in Central Asia" conducted by Pauline Jones, Center for Russian, East European, and Eurasian Studies at the University of Michigan, forthcoming.

${ }^{9}$ Interview with a local entrepreneur that runs a small guesthouse for tourists in Issik-Kul area, Bishkek, 2020.
} 
2019a, Azattyk 2019b, 2020). ${ }^{10}$ These investigations did not only expose the involvement of state bodies in transnational corruption schemes, but also stressed the connection between Matraimov and President Jeenbekov himself. Journalistic reports revealed strong ties between Matraimov's "customs empire" and members of the elite, suggesting that corruption was covered up at the top. These publications spurred a series of citizen protests called "ReAksia!" (Russian: ReAction) calling on authorities to launch an official investigation into the case and bring Matraimov to justice (Kloop.kg 2019, 24.kg 2019). Despite pressure coming from liberal civil society, the president kept denying Matraimov's involvement in corruption and even went as far as "authorizing" his newly established party "Mekenim Kyrgyzstan" to run in the parliamentary election. Following the election outcomes, three parties of power including "Mekenim Kyrgyzstan" won 107 out 120 places thanks to massive electoral fraud involving the use of "administrative resources," vote buying, and others means (Kaktus media 2020c). The forged victory of three parties of power left popular opposition parties such as "Butun Kyrgyzstan," "Mekenchil," "Chon Kazat," and "Ata-Meken" outside of the system. For the protesters it meant that not only their demands were ignored but that the most controversial figure was going to receive a mandate and most likely continue his illegal business under a newly received immunity from prosecution.

Abuse of power by the ruling regime-oligarchy tandem and flagrant electoral fraud featured prominently as the reasons why ordinary citizens took to the streets on October 5th. In a national poll, conducted in August 2020, only $1 \%$ of respondents stated they would vote for Matraimov's party, 5\% for the President's party and 2\% for another party of power- "Kyrgyzstan," if elections were held today (IRI 2020). However, the official election results demonstrated almost $57 \%$ cumulatively for the three parties, raising questions about the possibility of use of vote-buying prior to the election and other electoral fraud. Many protesters expressed their distrust towards the official election results. In interviews with the author, peaceful protesters also stressed a continuity between this mass uprising and earlier protests of "ReAction," thus highlighting a year-long public struggle against corrupt patronal presidentialism: "I took part in previous protests of "ReAction" and this time came out to protest again. Participation in the "ReAction" was helpful as I saw how the President covered up for Matraimov's corruption, how the elections were dirty and that only parties of power got elected. These outraged me deeply in my heart."11

By the end of the summer peak of the pandemic and prior to the election, $53 \%$ of the Kyrgyz population thought that the country was heading in the wrong direction, whereas $41 \%$ saw it going in the right direction. The poll shows that since 2017 , the year of Jeenbekov's election, a decline of the positive outlook on the country's

\footnotetext{
${ }^{10}$ On December 9, 2020, the U.S. Department of the Treasury's Office of Foreign Assets Control (OFAC) designated Raim Matraimov under the Global Magnitsky Human Rights Accountability Act "for being a foreign person who is a current or former government official responsible for or complicit in, or directly or indirectly engaged in, corruption, including the misappropriation of state assets, the expropriation of private assets for personal gain, corruption related to government contracts or the extraction of natural resources, or bribery".

${ }^{11}$ Interview with a protest participant, Bishkek, 2020.
} 
development from 66 to $41 \%$ took place, whereas the negative outlook went up from 23 to $53 \%$. A similar trend in the decline of the positive outlook from 63 to $28 \%$ was observable in 2010, the year of the "April Revolution" (IRI 2020).

\subsection{The "Revolutionary Situation": Salience of Political Ideas and Public Perceptions Amid the Mundane Struggle for Power}

While the contextualization of popular discontent clarifies the situation in which the dominant political machine was challenged, it can hardly explain the unexpected rise of populist Sadyr Japarov as a new national leader and his subsequent winning of the presidential elections in January 2021. The immediate dynamics of the struggle for power, which unfolded among numerous opposition leaders following the mass uprising, are one element to understanding why other opposition leaders lost to Japarov. But most importantly, the struggle outcomes were shaped, to the surprise of competing elites, by the underlying societal cleavages manifested through protest politics. In recent years, in the absence of genuine party programs, social protests became important expressions of cleavages existing in Kyrgyz society. In public discourses, these cleavages were hyperbolically framed as "liberal pro-western urban middle class" versus the "conservative pious poor class." Although these frames were constructed through years by both social and political actors, they nevertheless reflect the growing polarization of society due to long-existing problems. Consequently, the initial contestation of the patronal presidentialism ceased to be a mere struggle for power and acquired a salient ideational dimension about the ways the country should develop after Jeenbekov's demise. Japarov's victory and the loss of "liberal" opposition forces were due to these cleavage politics in which conservative nationalist and religious values prevailed. Below I dissect these ideational and power struggles that unfolded in Bishkek's main public squares.

Labeling the October uprising as a "Youth Revolution," foreign and domestic media put forward young people who were angry with the results of rigged election and corruption. The initial peaceful protest attracted citizens from all sectors of society: liberal Bishkek urbanites, as well as the suburban poor and rural residents who traveled from the countryside. It was a largely spontaneous, leaderless, and chaotic mobilization comprised of either solitary individuals or groups of people based on neighborhood and friendship. ${ }^{12}$ Protesters began assembling at the Ala-Too plaza by noon, waiting for more news about the election outcomes and the authorities' response. Representatives among youth activists, celebrity figures and youth wings of political parties were politicizing the crowd. No major opposition leader had yet made an appearance. Closer to the evening, when opposition politicians began galvanizing

\footnotetext{
12 I discuss these dynamics more in detail in Doolotkeldieva, A. (2021a). Power and space in social mobilizations: Preliminary thoughts about protests that led to a change of government in Kyrgyzstan in October 2020. Central Asian Program Papers, 251.
} 
the crowds, a sudden call to storm the White House provoked a split in the peaceful movement. Part of the protest crowd left the main square, disagreeing with this violent development, while others moved toward the White House, which is only a hundred meters away, and began clashing with the police. Still, more protesters were joining the evening developments, freshly arrived from the suburbs and the countryside. Cut off from any Internet connection, their individual and group movements around the White House and Ala-Too square were chaotic and participants reported to the author that they were not fully understanding the course of actions.

Taking advantage of this major development, supporters of opposition politicians went to storm the Special Security's remand prison and other prisons to illegally free their leaders. The release of prisoners and mobilization of their supporters in the night between October 5 and 6 might suggest that the uprising was pre-meditated, and not spontaneous. ${ }^{13}$ Indeed, both Japarov and former president Atambaev were known as President Jeenbekov's opponents and both displayed in the past their potential to deploy supporters to fight. Moreover, among the visiting protesters, Issik-Kul residents dominated due to the geographic origins of several opposition leaders such as the heads of "Mekenchil" and "Chon Kazat" parties. This geographic domination might also imply the uprising's pre-organized character. However, not all Issik-Kul residents were supportive of these parties ${ }^{14}$ and residents from other regions were present as well. Also, there were reports in mass media that Japarov's supporters were bused to, lodged at, and fed at one of the capital's hotels (Kaktus media 2020b). ${ }^{15}$ This raised questions about the authenticity of his fellowship that came in masses in the subsequent days after the initial uprising to rally on his side. Finally, the involvement of the so-called "sportsmen" on the side of politicians during the October events also challenged the original image of peaceful citizen mobilization. Peaceful protesters among ordinary citizens reported to the author that groups of "provocateurs" were operating in the crowds, shouting out calls to storm the White House and support different politicians. Some urban dwellers were repulsed by these fast developments, they felt betrayed as if their democratic impulse was hijacked by "regressive forces," and many retracted from the protest: "I came to the protest because I thought it would be peaceful. I support only peaceful means because I do not want to become a tool in someone's hands like in the previous revolutions. I thought that the new generation of citizens grew up to this conscious level. But our initial movement was stolen. We lost control over the revolution...I withdrew from it when I saw the unfolding dirty struggle." 16

\footnotetext{
${ }^{13}$ Russian experts on Kyrgyzstan's uprising "Protesty v Kyrgyzstane priveli k smene vlasti v strane" [Protests in Kyrgyzstan led to the change of government in the country], October 7, 2020, https://www.golosameriki.com/a/protests-in-kyrgyzstan-led-to-a-change-of-government-inthe-country/5611953.html, accessed 24.02.21.

${ }^{14}$ Interviews with Issik-kul residents who have participated in the October uprising, Bishkek, 2020.

${ }^{15}$ Sportsmen refer to young people, usually members of martial arts clubs who are frequently mobilized by politicians in power contestations.

${ }^{16}$ Interview with a protester, 28, Bishkek resident, program manager at an international organization, Bishkek, 2020.
} 
From this moment on, the line between the initial genuine popular mobilization and organized manpower became blurred. The release of various regime opponents, which was outside of the regime's calculus, ${ }^{17}$ put a beginning to a fierce struggle for power in the absence of a strong position from President Jeenbekov. The latter was missing for several days and his press secretary stated that he was working online (Fergana.ru 2020b). Two opposing groups formed around a nationalist coalition under Japarov's leadership and a "liberal" coalition including the former Prime Minister and oligarch Omurbek Babanov, respectively (Fergana.ru 2020a). The latter coalition was a heterogenous group comprised of politicians and parties who were compelled to cooperate in the face of their main competitor, Japarov. The coalition involved liberal right-wing parties "Bir-Bol," "Reforma," and "Respublica" on the one hand, the oldest political parties claiming a socialist leaning_- "Ata-Meken" and "SDPK," and nationalist parties "Butun Kyrgyzstan" and "Zamandash" on the other hand. Both Japarov and Babanov were competing to become Prime Minister, but Japarov was also torpedoing the president's mandate and pushing for a constitutional reversal towards strong presidentialism. Babanov's group, heterogeneous as it is, nevertheless was united around, and differed from Japarov on, the semi-parliamentary constitutional design, thus earning the public label "liberal." While Japarov was calling his supporters to grab power and give it, in a populist move, to the people, Babanov's group urged protesters to go back to legality and constitutionality. Yet, these calls did not resonate with the majority as that very constitution failed to protect the rights of the poor and benefited the rich only.

The temporary union of liberals proved to be too unnatural, also for the reasons of generational splits. Youth activists from "Reforma," "Bir-Bol" and "Ata-Meken" parties, who were the driving force on the streets and who were seeking to represent "new politics," were against cooperation with the old guard. The latter were denied access to speak up, humiliated by the youth crowds, and ousted from the public stage. Several youth leaders launched an internal competition, leading even Tilek Toktogaziev from “Ata-Meken" party to self-pronounce as Prime Minister and others to take over state ministries. The final blow to the union came when an indecisive Babanov decided to coalesce with former president Almazbek Atambaev, by now a highly controversial figure. ${ }^{18}$ This strategy was thought as the only viable option to offset the rising Japarov. Disagreeing with this move, the youth wing of the coalition condemned the union with Atambaev and launched street resistance under the slogan "Out with the oldies!" It was their attempt to not let the old guard appropriate the protest movement as it happened in previous revolutions of 2005 and 2010. As members of these youth wings reported to the author: "We did not launch this revolution to go back to old politics, to old corrupt politicians! These party bosses carried out strategies that were contrary to our visions and ideals. If we backed them up, we would prove that we are no better than them and that nothing changes in our

\footnotetext{
${ }^{17}$ Interviews with members of elites, Bishkek, 2020-2021.

${ }^{18}$ Actually, some members of this coalition personally suffered in Atambaev's hands. Leadership of "Ata-Meken" party, MP Omurbek Tekebaev, had been imprisoned whereas Babanov himself was prosecuted under late Atmabaev's rule.
} 
country. We also risked losing our followers among the young generation. So, we wanted to elect our own leader, among the youth, as a Prime Minister."19

While the liberals were sending mixed signals to the public, exposing a severe lack of integrity, Japarov's group had quickly and skillfully moved to consolidate protesters around their claims for power by framing the uprising as anti-regime and anti-elite. A combustible mass aggregated the suburban poor, nationalist youth, and religious conservatives, long ignored by the establishment, in his support. Japarov's nationalist language against the corrupt establishment has attracted multiple grassroots activists and associations who had been fighting against "irresponsive state" and corrupt elites through these years. ${ }^{20}$ During these days, he managed to attract followers with the help of populist ideas of nationalizing natural resources, giving power to the people, punishing the rich, reaching territorial sovereignty, etc. His identity as an "ordinary guy," a martyr, a "patriot" with a record of fighting for national interests against global corporations distinguished him as a "true Kyrgyz" against the liberal coalition which was associated with the rest of the corrupt establishment. It is via his populist reference to "the people's power" that he succeeded to pressure on the parliament to vote him as a Prime Minister after a third attempt, to appoint his friend to the steer the security apparatus, and to point another friend as a new Speaker of the parliament. His meteoric rise to power would be impossible without this early mass support which he skillfully exploited when capturing one bastion of power after the next. As his supporters, participating in daily rallies that I observed on the "old square," stated: "Japarov listens to us, he is with the people. Let's give him a chance, let's give him the power. He promised to clamp down on bloodsuckers who have been stealing our money and he promised to bring natural resources to the people's control. I support these ideas."21

During the week between October 6 and 13, the public squares of the capital turned into the battle grounds of two opposing camps rallying to gain supporters and showing strength in their attempts to grab power. The struggle grew out of control when representatives of the liberal camp were ousted from Ala-Too square, some of them were attacked and people allegedly close to Japarov shot at Atambaev's departing car (Kommersant 2020b). Facing the risk of destabilization, President Jeenbekov sought to negotiate his own stay in power by granting legitimacy to one of these camps. The choice was not complicated: his lasting rivalry with Atambaev, whom he sacked and imprisoned after being brought to power by him, determined his option for Sadyr Japarov. ${ }^{22}$ Russian President Vladimir Putin's deputy head of administration, Dimitry Kosak, flew personally to Bishkek in order to seal the deal

\footnotetext{
${ }^{19}$ Interview with a youth activist close to "Ata-Meken" party, Bishkek, 2020.

${ }^{20}$ I discuss the rise of nationalist populism amid violent change of government in October 2020 more in detail in Doolotkeldieva, A. (2021b). Populism à la Kyrgyz: Sadyr Japarov, nationalism, and anti-elite sentiment in Kyrgyzstan. Illiberalism Studies Program Working Papers, 4.

${ }^{21}$ Short discussions with a dozen ordinary citizens who participated in rallies in support of Japarov during the October events, Bishkek, 2020.

${ }^{22}$ What is interesting is that the liberals did not seek Jeenbekov's ouster as they saw in him a counterbalance to Jaaparov. It was feared that his removal could lead to a major destabilization along the North/South cleavage and ethnic clashes like in the aftermath of the 'April Revolution'
} 
between the president and the newcomer Japarov (Kommersant 2020a). However, neither the president nor the Russians expected that the group they had helped to legitimize would breach the agreement soon after and force him to resign.

While initially, the protesters had only demanded the annulation of election results, Jeenbekov's removal was unexpected and suspicious. This development plunged the country into uncertainty about the future and possible worrisome involvement of organized crime as several members of parliament, journalists, and public figures hinted at pressure exerted by criminals (Kaktus media 2020a). ${ }^{23}$ Having the majority of elite loyalty and international backing, President Jeenbekov could have, perhaps, avoided his deposing by swiftly conceding to protesters' initial demands and acknowledging the electoral fraud. Without popular mobilization, the street opposition would not have been able to contest the regime.

The week in which the liberals and the populist Japarov fought for power was decisive for the outcome of the uprising and, if not for the strategic mistakes committed by the liberals, Omurbek Babanov stood a real chance to take over as he was twice as popular (16\%) as Sadyr Japarov (8\%) in August 2020. ${ }^{24}$ Babanov's alliance with the old guard and the lack of a political vision repulsed the young generation who sought to depart from old politics. The latter's withdrawal demonstrated the strength of antielite moods in society across classes and the urban/rural divide. Yet while united in anti-establishment sentiments, the initial cross-class and cross-cleavage movement got quickly splintered into divergent visions of politics that formed along more nationalist and more liberal values. Gabdulkhakov (2020) interpreted this confrontation as a civilizational clash between "the progressives and the orcs" following public discourses in Kyrgyzstan's social media and Ismailbekova (2020) saw in them a generational split. During this week, societal polarization indeed took on the following divides: language (Russophone vs. Kyrgyz), liberal versus conservative values, secular versus religious beliefs, cosmopolitan versus nationalist views, and poor versus middle-class division. Thus, the minority Russophone urbanites rallied around the liberal forces and the conservative majority of the working class and the poor-around Japarov. This polarization was decisive for Sadyr Japarov's victory.

Once President Jeenbekov was removed, the Kyrgyz establishment closed ranks behind the future President Sadyr Japarov, allowing him a fast capture of the state in the run-up to the presidential elections. This story is a culmination of increasing societal inequalities and rising nationalism as a response to the former, which in the absence of true political representation and left-wing programs became manifested via protest-making. It also shows that money did not guarantee the country's

of 2010. Interviews with representatives of "Reforma" and "Ata-Meken" political parties, Bishkek, 2020.

${ }^{23}$ On the role of mafia in previous revolutions see Kupatadze, A. (2015). Political corruption in Eurasia: Understanding collusion between states, organized crise and business. Theoretical Criminology, 19 (2), 198-215; Marat, E. (2006). The state-crime nexus in Central Asia: State weakness, organized crime, and corruption in Kyrgyzstan and Tajikistan. Central Asia-Caucasus Institute \& Silk Road Studies Program.

${ }^{24}$ His popularity fell to $3 \%$ in contrast to Japarov's $51 \%$ in December 2020. See https://www.iri. org/sites/default/files/iri_kyrgyzstan_poll_dec_2020_eng.pdf, accessed 31.01.21. 
richest and well-established politicians Atambaev and Babanov popular support and following. Their dramatic fallout with protesters exposed an acute crisis of authentic figures to an extent that the population was ready to entrust a former inmate with more credit than the old guard. However, what this spectacular street struggle hides is the third story of an internal regime-oligarchy dynamic which in all probability would have shaken the regime stability in the near future.

\subsection{Parliamentary Coup in the Making: Regime Versus Oligarchy?}

Kyrgyzstan's political system has been an oligarchy to the extent that family-type kleptocracies exercised minority power with a varying degree of inclusion of regime cronies. With the shift to an emerging party system in 2010 , it can be assumed that this minority power became accessible to wider circles of the country's richest citizens. Research in Eurasia accounts for changing regime-oligarchy relationships as an important dynamic for regime stability (Guriev and Rachinsky 2005; Junisbai 2010). I contend that this critical dynamic was present in the last year of Jeenbekov's rule, but the disruption of his political machine by the mass uprising prevented its full unfolding. In this section, I return to the changing nature of the patronal presidentialism under increased pluralism, which includes further oligarchic power. It seems worth expanding on the ways the co-existence of a pluralistic system with an oligarchy can shift the balance towards the latter's bigger influence. ${ }^{25}$

Oligarchization of Kyrgyz politics began in the 1990s and was part of the statebuilding processes (Radnitz 2010) leading further to the rise of a rentier class (Sanghera and Satybaldieva 2020). Previous research indicates how family kleptocracies and their cronies tapped into the state resources to enrich themselves (Cooley and Heathershaw 2017; Nakaya 2009; Doolotkeldieva and Heathershaw 2015), and how the state served as an "investment market" to generate direct rents (Engvall 2016). Further research is required to investigate the ongoing oligarchization of politics, but a preliminary observation suggests that the emergent party system added new possibilities for the richest class to influence policies and informal decisions favorable to their interests. This observation accounts for the ways political parties used their constitutionally increased powers to form the government and potentially tap into the state ministries as a resource. However, to participate in highly competitive parliamentary elections, parties faced an acute problem of funding. Sponsorship by businessmen/oligarchs became the sine qua non to managing electoral campaigns. This was practically done by selling seats in closed electoral party lists, with the first top ten to twenty seats worth between 500 thousand and a million dollars in a country with only an $\$ 8.5$ billion GDP (Current time 2019). The monetization of the electoral party lists led to an increased number of rich people either directly elected to

\footnotetext{
${ }^{25}$ For an account of oligarchy as a global historical norm see Winters, J. (2012). Oligarchy. Cambridge University Press.
} 
the parliament (Ukushov 2017) or informally exerting influence on party bosses via funding. For example, the notorious Matraimov brothers, one of whom was elected to the parliament in 2015 inside the then-President Atambaev's party, allegedly financed the electoral campaigns of several political parties (Gezitter.org 2019; Vb.kg 2019), the presidential campaign of Jeenbekov in 2017, and even Japarov's recent presidential campaign (Kloop.kg 2020b). These insights were covered in the press but also claimed in the interviews with members of the elite. ${ }^{26}$

Employing their new constitutional powers, the parliamentary groups appointed their ministers and, in this way, "divided" the state among themselves (Engvall 2013). Oligarchs who had entered this system began employing their access to the state to return their prior investments in the elections. However, Jeenbekov's regime had allowed for a degree of incorporation of oligarchs into the state system that became a risk for regime stability. Elite interviews suggest that he was in a much more dependent position vis-à-vis oligarchy than the previous presidents. Because Matraimov, also known as "Raim-million," allegedly financed his electoral campaign in 2017 , Jeenbekov could not succumb to public pressures and look into Matraimov's corruption case. Due to this relationship of dependency, he also allowed Matraimov's party to run in the parliamentary election and win.

However, Matraimovs' great potential to buy off votes ${ }^{27}$ in the run-up to elections and their rising authority among members of parliament provoked fears in Jeenbekov's entourage. The president's brother, MP Asylbek Jeenbekov, was particularly warry that Matraimov's party would outbid the presidential party "Birimdik" and be granted the right to form the government. Enjoying the loyalty of a comfortable majority of MPs, this situation could lead to a parliamentary coup. ${ }^{28}$ Asylbek Jeenbekov's concerns were attached to Matraimovs rising authority among the elites. By relying on the power of money, they succeeded in placing their people inside the state security apparatus, law enforcement, and the courts. They used access to the state to also disburse resources to their clients among the elites. By getting things done for them, they earned the reputation of effective doers in contrast to the "undecisive" and "slow" president Jeenbekov. As one MP claimed, "President Jeenbekov's favourite method was deception. He would promise to fix your issue but would never do it in reality. Matraimovs, on the contrary, have always fulfilled their promises. They had loyal people placed everywhere: in the police, courts, regulatory bodies. Our deputies realized that Matraimovs' power was far-reaching and more efficient. Turning to them, rather to the president, was a guarantee of a successful resolution of your business." 29

\footnotetext{
${ }^{26}$ Interviews with four MPs, Bishkek, 2020.

${ }^{27}$ According to the Central Election Commission, Matraimov's "Mekenim Kyrgyzstan" party has officially spent $\$ 1,659,000$ for its electoral campaign making it the richest runner. Figures in U.S. dollars are approximate due to dramatic fluctuations in the exchange rate. See Kloop.kg (2020). Odnim grafikom: Skol'ko partii potratili na Vybory-2020 [online]. Available at: https://kloop.kg/ blog/2020/10/04/odnim-grafikom-skolko-partii-potratili-na-vybory-2020/. Accessed February 17, 2021.

${ }^{28}$ Informal interviews with members of parliament, Bishkek, 2020.

${ }^{29}$ Interview with a member of parliament, Bishkek, 2020.
} 
By summer 2020, the Matraimov brothers succeeded in co-opting a significant part of the elites by incorporating them into their electoral party list. According to an informant inside the government, MPs were competing among each other for a seat on the list due to the high chances of this party's electoral success. Although the electoral lists of all "parties of power," including the Matraimov's, was initially coordinated by the president, the growing competition between the president's brother and the Matraimovs led to a more chaotic electoral technology than traditionally. The competition caused confusion among the elites about the locus of decision-making. As one MP claims, "In spring 2020, deputies were confused about which party to join. Joining Matraimov's party was lucrative but that would entail a risk of falling out with the president. Deputies were confused as to who takes a decision about the future composition of elites and were afraid of making wrong movements. Everyone was expecting the election day to see the culmination of this internal fight."30

Indeed, as the electoral outcomes of the October elections show, the Matraimov's party was just $0.71 \%$ behind the presidential party "Birimdik," if one can trust at all these official results after reported frauds. ${ }^{31}$ This electoral outcome, perhaps, validates Jeenbekov's concerns about the rising challenge from the oligarchy. It is, of course, in the domain of speculation to ask what would happen to regime stability with Matraimovs coming just under $1 \%$ behind the presidential party. But this case is useful in showing how the emergent party system has provided additional avenues for the rich people to influence politics in the absence of a robust system of checks and balances and weak state institutions. Time will show whether the suspicions hinting at Matraimov's possible financing of the new president's presidential campaign are false or true, as it would mean the continuous influence of oligarchy on Japarov's patronal presidentialism.

\subsection{Conclusion}

The violent change of government in Kyrgyzstan in October 2020 can be best understood as a combination of three distinct stories coming together under an unprecedented external shock produced by the coronavirus. First, a genuine citizen mobilization was triggered by the pandemic-related economic decline and rigged elections. Second, the initial peaceful protest was hijacked, to the surprise of the many, by a populist leader capitalizing on long-existing societal polarization. Third, the spectacular unfolding of the intra-opposition struggle downplays an important process of oligarchization, underlying the shaky grounds of patronal presidentialism in pluralist systems. This last development has exactly led Sadyr Japarov to initiate, in a populist move, a constitutional reversal to strong presidentialism and away from pluralism. At the time of writing this paper, a referendum was scheduled to vote for a new

\footnotetext{
${ }^{30}$ Interview with a member of parliament, Bishkek.

31 Official website of the State Commission for Elections: https://newess.shailoo.gov.kg/ru/election/ 11098/ballot-count?type=NW_ROOT.
} 
constitution in which the president becomes the head of the executive, with no rules governing the electoral system publicly available and a reduced role of the parliament.

\section{References}

Alexander LG, Bennett A (2005) Case studies and theory development in the social sciences. MIT Press, Cambridge Massachusetts

Cooley A, Heathershaw J (2017) Dictators without borders. Power and money in Central Asia. New Haven and London, Yale University Press

Current time (2019) V deputaty za \$ 500 tysyach. Kto pokupaet mesta v parlamente Kyrgyzstana [online]. https://www.currenttime.tv/a/parliament-seats-on-sale/30219729.html. Accessed February 2, 2021.

Doolotkeldieva A, Heathershaw J (2015) State as resource, mediator and performer: understanding the local and global politics of gold mining in Kyrgyzstan. Central Asian Survey 34(1):93-109

Doolotkeldieva A, Wolters A (2017) Uncertainty perpetuated? The pitfalls of a weakly institutionalized party system in Kyrgyzstan. Central Asian Affairs 4(1):26-50

Doolotkeldieva A (2021a) Power and space in social mobilizations: Preliminary thoughts about protests that led to a change of government in Kyrgyzstan in October 2020. In: Central Asian Program Papers, 251

Doolotkeldieva A (2021b) Populism à la Kyrgyz: Sadyr Japarov, nationalism, and anti-elite sentiment in Kyrgyzstan. In: Illiberalism Studies Program Working Papers, 4.

Engvall J (2013) The political sources of Kyrgyzstan's recent unrest [online].https://www.cacian alyst.org/publications/analytical-articles/item/12766-the-political-sources-of-kyrgyzstans-rec ent-unrest.html?tmpl=component\&print=1. Accessed 20 Feb 2021

Engvall J (2016) The state as investment market. In: Kyrgyzstan in comparative perspective. University of Pittsburgh Press.

Fergana.ru. (2020a). Chetyre politicheskie partii Kyrgyzstana vydvinuli Omurbeka Babanova na post premiera [online]. https://fergana.site/news/121111/. Accessed 2 Feb 2021

Fergana. Ru. (2020b). Jeenbekov vyshel na svyaz i gotov podpisat ukazy o novyh naznacheniah. https://fergana.site/news/121103/. Accessed 2 Feb 2021

Fumagalli M (2016) Semi-presidentialism in Kyrgyzstan. In Semi-presidentialism in the Caucasus and Central Asia. London, Palgrave Macmillan

Gabdulhakov R (2020) The avengers vs the Orcs: social media nuances in Kyrgyzstan's (almost) third revolution. https://ru.plovism.com/post/the-avengers-vs-the-orcs-social-media-nuances-inkyrgyzstan-s-almost-third-revolution. Accessed 23 Feb 2021

Gezitter.org (2019) Partiu Zamandash finansiruet Matraimov? https://www.gezitter.org/ushaktar/ 79374_partiyu_zamandash_finansiruet_matraimov/. Accessed 2 Feb 2021

Golos Ameriki (2020) Protesty v Kyrgyzstane priveli k smene vlasti v strane. https://www.golosa meriki.com/a/protests-in-kyrgyzstan-led-to-a-change-of-government-in-the-country/5611953. html. Accessed 2 Feb 2021

Guriev S, Rachinsky A (2005) The role of oligarchs in Russian capitalism. J Econ Perspect 19(1):131-150

Hale HE (2005) Regime cycles: democracy, autocracy, and revolution in post-Soviet Eurasia. World Politics 58(1):133-165

Hale HE (2013) Did the Internet break the political machine? Moldova's 'Twitter Revolution that wasn't. Demokr: J Post-Sov Democr 21(3):481-505

Huskey E (2007) Eurasian semi-presidentialism: The development of Kyrgyzstan's model of government. In: Semi-presidentialism outside Europe: a comparative study. Routledge, London

IRI (2017) Public opinion poll: residents of Kyrgyzstan. February 15-March 2, 2017 
IRI (2019) Public opinion poll: residents of Kyrgyzstan. https://www.iri.org/sites/default/files/final_ kygyzstan_slides.pdf. Accessed 2 Feb 2021

IRI (2020) Public opinion poll: residents of Kyrgyzstan. August 6-August 15. https://www.iri.org/ sites/default/files/kyrgyzstan_august_2020_slides_public_release.pdf. Accessed 20 Feb 2021

Jones P (Forthcoming) Social and political impact of COVID-19 in Central Asia. NSF and the Center for Russian, East European, and Eurasian Studies at the University of Michigan

Junisbai B (2010) A tale of two Kazakhstans: sources of political cleavage and conflict in the post-Soviet period. Eur Asia Stud 62(2):235-269

Kaktus media (2020a) Aida Kasymalieva o tom chto proishodilo v gosrezidencii I kto daval komandy deputatam. https://kaktus.media/doc/423280_aida_kasymalieva_o_tom_chto_proisho dilo_v_gosrezidencii_i_kto_daval_komandy_depytatam.html. Accessed 2 Feb 2021

Kaktus Media (2020b) Kto predostavil gostinitsu 'Ak-Keme' mitingyiushchim? Gosorgany svalivaiut drug na druga. https://kaktus.media/doc/423787_kto_predostavil_gostinicy_ak_keme_miti ngyushim_gosorgany_svalivaut_dryg_na_dryga.html. Accessed 2 Feb 2021

Kaktus media (2020c). Predvaritelny spisok deputatov VII sozyva Jogorku Kenesha. https://kak tus.media/doc/422474_predvaritelnyy_spisok_depytatov_vii_sozyva_jogorky_kenesha.html.

Accessed 2 Feb 2021

Kloop.kg (2019) V Bishkeke i ne tolko. "Re:Aktcia" Kyrgyzstancev v drugih gorodah mira. https:// kloop.kg/blog/2019/11/25/v-bishkeke-i-ne-tolko-re-aktsiya-kyrgyzstantsev-v-drugih-gorodahmira/. Accessed 2 Feb 2021

Kloop.kg (2020a) Odnim grafikom: Skol'ko partii potratili na vybory-2020. https://kloop.kg/blog/ 2020/10/04/odnim-grafikom-skolko-partii-potratili-na-vybory-2020. Accessed 2 Mar 2021

Kloop.kg (2020b) 12 druzei Sadyra: kto financiruet izbiratelnuu kampaniu Japarova? https:// kloop.kg/blog/2020/12/23/12-druzej-sadyra-kto-finansiruet-izbiratelnuyu-kampaniyu-zhapar ova/. Accessed $10 \mathrm{Feb}, 2021$

Kommersant.ru (2020a) Kosak vstretilsa v Bishkeke s prezidentom Kirgizii. https://www.kommer sant.ru/doc/4530007. Accessed 2 Feb 2021

Kommersant.ru (2020b) V Bishkeke strelyali v mashinu ex-presidenta Atambaeva. https://www. kommersant.ru/doc/4528272. Accessed 2 Feb 2021

Kupatadze A (2015) Political corruption in Eurasia: understanding collusion between states, organized crise and business. Theor Criminol 19(2):198-215

Marat E (2006) The state-crime nexus in Central Asia: state weakness, organized crime, and corruption in Kyrgyzstan and Tajikistan. Central Asia-Caucasus Institute \& Silk Road Studies Program.

Nakaya S (2009) Aid and transition from a war economy to an oligarchy in post-war in Tajikistan. Central Asian Survey 28(3):259-273

Ó Beacháin D, Polese A (2008) American boots and Russian vodka: external factors in the colour revolutions of Georgia, Ukraine and Kyrgyzstan. Totalitarismus und Demokratie 5(1):87-113

Ob itogah vyborochnogo obsledovania. Vlianie pandemii Covid-19 na domashnie hozyastva. 15 October and 15 November 2020.

OCCRP (2019) The 700-million-dollar man. https://www.occrp.org/en/plunder-and-patronage/the700-million-dollar-man. Accessed 2 Feb 2021

Pelkmans M (2005) On transition and revolution in Kyrgyzstan. Focaal: J Glob Hist Anthropol 46:147-157

Radio Azattyk (2019a) Istoria Aierkena Saimati, otmyvshego 700 millionov dollarov cherez Kyrgyzstan. https://rus.azattyk.org/a/kyrgyzstan-azattyk-occrp-kloop-joint-investigation/ 30286844.html. Accessed 2 Feb 2021

Radio Azattyk (2019b) Kak iz Kyrgyzstana vyveli sotni millionov dollarov. https://rus.azattyk.org/ a/30285881.html. Accessed 2 Feb 2021

Radio Azattyk (2020) ReAction 3:0: Obchestvennost v ojidanii reshenia vlastei. https://rus.azattyk. org/a/30699889.html. Accessed 2 Feb 2021

Radnitz S (2010) The color of money: Privatization, economic dispersion, and the post-Soviet "revolutions." Comp Polit 42(2):127-146 
Reeves M (2010) Breaking point: why the Kyrgyz lost their patience. https://www.opendemocracy. net/en/odr/breaking-point-why-kyrgyz-lost-their-patience/. Accessed 13 Feb 2021

Sanghera B, Satybaldieva E (2020) The other road to serfdom: The rise of the rentier class in post-Soviet economies. Soc Sci Inf 59(3):505-536

Tucker JA (2007) Enough! electoral fraud, collective action problems, and post-communist colored revolutions. Perspect Polit 5(3):535-551

Ukushov M (2017) Kyrgyzstan i parliamentskaia forma pravlenia: Opyt razocharovania. http:// www.center.kg/article/99. Accessed 2 Feb 2021

Vb.kg (2019) Raimbek Matraimov finansiruet partiu Ata-Meken? https://www.vb.kg/doc/383420_ rayymbek_matraimov_profinansiryet_partiu_ata_meken.html. Accessed 10 Feb 2021

Vesterbye SD, Dzhuraev Sh, Marazis A (2020) Socio-economic impact of COVID-19 and media consumption among vulnerable communities in Central Asia. European Neighborhood Council Winters J (2012) Oligarchy. Cambridge University Press, Cambridge

Wooden AE (2014) Kyrgyzstan's dark ages: Framing and the 2010 hydroelectric revolution. Central Asian Survey 33(4):463-481

World Bank (2021) One year later in the Kyrgyz Republic's battle against Covid-19. https://www. worldbank.org/en/news/feature/2021/03/17/one-year-later-in-the-kyrgyz-republic-s-battle-aga inst-covid-19?fbclid=IwAR11CFcOu2dOV6bxTOU39Q9iKTflYkB991sU77hV7UG063o_fSzU 9KpSYtI. Accessed 2 Feb 2021

24.kg (2019) Miting \#ReAction 2:0 v Bishkeke. Kak etp bylo. https://24.kg/obschestvo/138362_ miting_REaktsiya_20v_bishkeke_kak_eto_byilo/. Accessed February 2, 2021.Abdyrakhmanov T.A., Kurbanova N.U. Problems of ethno-confessional relations in modern Kyrgyzstan: search for solutions/Islam in CIS. 03.11.2010. http://www.islamsng.com/kgz/opinion/404\#_ftn2

Open Access This chapter is licensed under the terms of the Creative Commons Attribution 4.0 International License (http://creativecommons.org/licenses/by/4.0/), which permits use, sharing, adaptation, distribution and reproduction in any medium or format, as long as you give appropriate credit to the original author(s) and the source, provide a link to the Creative Commons license and indicate if changes were made.

The images or other third party material in this chapter are included in the chapter's Creative Commons license, unless indicated otherwise in a credit line to the material. If material is not included in the chapter's Creative Commons license and your intended use is not permitted by statutory regulation or exceeds the permitted use, you will need to obtain permission directly from the copyright holder. 